\title{
A közösségi média szerepe a fesztiválturizmusban - a Szegedi Ifjúsági Napok és a Green Future példáján ${ }^{1}$
}

\author{
Szerző: Süli Dorottya² - Martyin-Csamangó Zita ${ }^{3}$
}

A technológia fejlódése és az internet térnyerése új trendeket indított el a turizmusban is. A közösségi média használatának terjedésével az élmények online megosztása, keresése egyre népszerúbbé válik, mely egyrészt befolyásolhatja az utazási döntések meghozatalát, másrészt hozzájárulhat az adott desztináció imázsának javitásához, ismertségének növeléséhez.

A fesztiválok, különösen a zenei fesztiválok évek óta egyre több-elsősorban fiatal - turistát vonzanak, akik túlnyomó többsége a közösségi hálózatokat használja élményei megosztására. Kutatásunk során a Szegedi Ifjúsági Napok és a Green Future fesztiválozói körében végeztünk kérdőives felmérést, melyben a közösségi média fesztiválturizmusra gyakorolt hatása mellett vizsgáltuk, hogy a megkérdezettek hogyan itélik meg a fesztiválok desztinációra gyakorolt hatásait. Ezek közül az imázserôsitô hatás megjelenését több módszerrel is vizsgáltuk.

Az eredmények alapján megállapítható, hogy a megkérdezett fesztiválozók nagy jelentôséget tulajdonítanak élményeik megosztásának és jelentôs arányban használják a közösségi médiát információk keresésére. Megállapitható az is, hogy a két könnyüzenei fesztivál hozzájárul a települések imázsának alakításához, hiszen mind a vizsgált bejegyzésekben, mind a válaszadók asszociációiban többször együtt jelentek meg.

Kulcsszavak: fesztiválturizmus, web 2.0, közösségi média, fesztivál hatások, imázserősítés.

\section{Bevezetés}

A XXI. században az internet nagy szerepet játszik a mindennapokban, így a turizmusban is. Ma már a világhálón szerzi a potenciális közönség az információkat, kiegészítve ezzel a hagyományos kommunikációs csatornákat (VERES et al. 2017). Ezen belül is a közösségi média térnyerése az egyik legszembetûnőbb, mely új trendeket, lehetőségeket teremt a turizmus számára. Ilyen lehetőség a tapasztalatok, élmények megosztása révén az utazási döntés befolyásolása. Az élmények online megosztása az Y és Z generáció (azaz az 1980 után született korosztály) körében egyre népszerúbbé válik (KLAUSZ 2017), melynek nagy elónye, hogy a megosztott élmények gyorsan és sokáig kereshetôvé válnak. Kutatásunk egyik célja ezen új trendek megjelenésének vizsgálata volt a fiatal fesztiválozók körében.

A fesztiválok látogatása, és ezáltal a fesztiválturizmus, napjainkban egyre népszerúbbé válik, amit az is bizonyít, hogy 2009 óta az Euroba-

\footnotetext{
${ }^{1}$ A kutatás az Emberi Erőforrások Minisztériuma UNKP-17-2 kódszámú Új Nemzeti Kiválóság Programjának támogatásával készült. ${ }^{2}$ hallgató, SZTE Gazdaság- és Társadalomföldrajz Tanszék, dorottya.suli@gmail.com

${ }^{3}$ tanársegéd, SZTE Gazdaság- és Társadalomföldrajz Tanszék, martyinz@geo.u-szeged.hu
}

rometer felmérések külön megnevezik a fesztivállátogatást, mint utazási motivációt és 6 év alatt 6\%os növekedés volt megfigyelhető a fesztivál, illetve rendezvény meglátogatása céljából tervezett utak számában (SULYOK - SZIVA 2009). A fesztiválokon belül nagy népszerúségnek örvendenek a zenei fesztiválok, melyek közül kutatásunk során a könnyúzenei fesztiválokra koncentráltunk, hiszen ezek elsősorban a fiatalabb korosztályok - mint a jövő utazói - körében népszerúek, így lehetóséget adnak a webkettő nyújtotta új lehetóségek megjelenésének vizsgálatára. Emellett kutatások bizonyítják, hogy mint a legtöbb turisztikai termék esetében, a fesztiválok által generált turisztikai forgalom következtében is megfigyelhetünk az adott desztinációban különböző közvetlen és közvetett környezeti, társadalmi-kulturális és gazdasági hatásokat (például növekvő bevételek, imázserôsítő hatás, zaj, szemetelés) (CROMPTON - McKAY 1994, LIANG et al. 2008, KUNDI 2012). Ezek közül az imázserősítő hatás külön kiemelendő, hiszen a fesztivállal kapcsolatos pozitív élmények javíthatják a település imázsát, és ezzel jelentősen befolyásolhatják a turisták utazási döntéseit, desztinációválasztását. Ezek alapján kutatásunk másik célja annak felmérése volt, hogy a fesztiválozók hogyan érzékelik ezeknek az eseményeknek a településre gyakorolt hatásait, különös hangsúlyt fektetve az imázserôsítő hatás megjelenésének több szempontú vizsgálatára. 


\section{A kutatás módszere}

Vizsgálatunkban kérdőíves felmérést végeztünk két - népszerúséget, idôpontot, programokat, megszólított korosztályt tekintve - hasonló jellegú fesztiválon, a Szegedi Ifjúsági Napokon (SZIN) és a Green Future-ön. Az elóbbi Szeged, az utóbbi Ada (Vajdaság) könnyúzenei fesztiválja, így az eredmények értékelésénél figyelembe vettük az eltéró földrajzi közegbő́l adódó különbségeket. Szeged a Dél-Alföld több mint 160 ezer fős (KSH 2017) regionális központja és egyetemi városa, széles turisztikai kínálattal, Ada viszont nagyjából 10 ezer fős észak-bácskai település ${ }^{5}$, mely főleg fürdőzésre alkalmas és kisebb turisztikai kínálattal rendelkezik. A településméretekhez hasonlóan látogatószámban is eltér a két fesztivál egymástól: a SZINen 2017-ben kb. 90 ezren, míg a Green Future fesztiválon nagyjából 24 ezren vettek részt. Mindkettő nyár végi, 4 napos könnyúzenei fesztivál, a Green Future-t 2017-ben augusztus 9-12., a SZIN-t augusztus 23-26. között rendezték meg. A meghívott előadók és programok tekintetében szintén hasonlóságot mutatnak, illetve közönségük is fóleg fiatalokból, egyetemistákból áll, azonban a SZIN esetében a résztvevők korcsoportja valamennyivel szélesebb. A felmérés során - az összehasonlíthatóság érdekében ${ }^{6}$ - elsősorban a 18-25 év közöttiek megkérdezése volt a cél, így nem tudtunk valószínúségi mintavételt alkalmazni, mely a vizsgált korcsoport felülreprezentálását eredményezte. A kérdőívek kitöltése a helyszínen, kérdezőbiztosok segítségével történt. A Green Future esetében 148, a SZIN-en 119 értékelhetó kérdő́ív került kitöltésre. A kérdőíves felmérés több kérdéskört is érintett, jelen tanulmányban a közösségi média használatának sajátosságaira, illetve a fesztiválok lehetséges hatásainak megítélésére térünk ki.

A vizsgált események imázserősítő hatásának megjelenését a kérdốivek mellett egy népszerú képmegosztó oldal (az Instagram) idevonatkozó bejegyzéseinek elemzésével is vizsgáltuk. A keresett kulcsszó (hashtag) mindkét esetben a fesztivál neve volt, de a SZIN esetében később az elemzést a \#szin2017-re korlátoztuk. Ennek oka, hogy a \#szin hashtag önmagában nagyon sok nem a fesztiválra vonatkozó tartalmat is megjelenített. A Green Future esetében 211, a SZIN esetében pedig 645 nyilvános posztot elemeztünk aszerint, hogy maga a település is megjelenik-e a hashtagek között. Az eredmények bemutatása elótt azonban érdemes röviden áttekinteni az idevonatkozó elméleti hátteret.

\footnotetext{
${ }^{4}$ http://www.ksh.hu/apps/hntr.telepules?p_lang=HU\&p id=33367

${ }^{5} \mathrm{http}: / /$ www.ada.org.rs/index.php/hu/a-mi-varosunk/telepuelesek/ada.html

${ }^{6}$ a kutatás folytatódik az egyetemisták körében végzett felméréssel
}

\section{3. Új trendek a turizmusban - a webkettố terjedése}

A turizmus egy információigényes iparág (BENCKENDORFF et al. 2014), ezért fontos megismerni azokat a technológiai, és a fogyasztói magatartásban bekövetkezô változásokat, amelyek hatással vannak az utazással kapcsolatos információk terjesztésére és hozzáférhetóségére (XIANG - GRETZEL 2010). A technológia és a mobilkommunikáció robbanásszerú fejlódése, illetve az internet térnyerése számos változást eredményezett, melynek hatása nem csak a mindennapi életben, hanem a szolgáltató szektorban, így a turizmusban is megfigyelhetó (DUDÁS et al. 2017). Egy a magyar lakosság körében végzett felmérés szerint a tájékozódás 64\%-ban az internet segítségével történik (VERES et al. 2017), ami napjainkra már az utazási döntések meghozatalának befolyásolási tényezői között az elsô helyen áll (XIANG et al. 2014). A turisták fó motivációjává az élményszerzés vált (KOVÁCS 2014), különösen az Y és Z generáció számára lett a legfontosabb cél az aktív turisztikai élmények szerzése és átélése (ÉBER 2008, SULYOK 2016).

A turisztikai termék sajátosságaiból adódóan azonban nehezen határozható meg előre, hogy milyen élményekben lesz része az adott turistának, ezért sokan utazási döntésüket mások közvetlen véleménye, tapasztalatai alapján (barátok, ismerősök javaslatára) hozzák meg. A turistáknak, annak érdekében, hogy csökkentsék az utazás körüli bizonytalanságot, megbízható forrásból kell tudniuk, hogy mi várhat rájuk az adott desztinációban (ŽIVKOVIĆ et al. 2014). Ennek ad egy új lendületet a web 2.0 technológia elterjedése, vagyis azok az internetes szolgáltatások, amelyekben a felhasználók közösen készítik a tartalmat, illetve megosztják egymás információit (ESZES 2007). A web 2.0 technológiáknak köszönhetóen ugyanis az internet egy „közzétételi-böngészési” platformról "részvételi-interakciós" platformmá alakult (XIANG et al. 2014), mely jelentősen befolyásolta és megváltoztatta az utazási döntéshozatali folyamatot (BUHALIS - LOW 2008). A turistáknak ma már számos közösségi oldalon lehetőségük van az utazással kapcsolatos saját élményeik, tapasztalataik megosztására, melyet később főként a fiatalabb korosztályok információforrásként használnak utazásuk előtt vagy alatt (XIANG GRETZEL 2010) (1. ábra). 
1. ábra fényképei befolyással vannak az utazási terveire.

A közösségi média és a turizmus kapcsolata

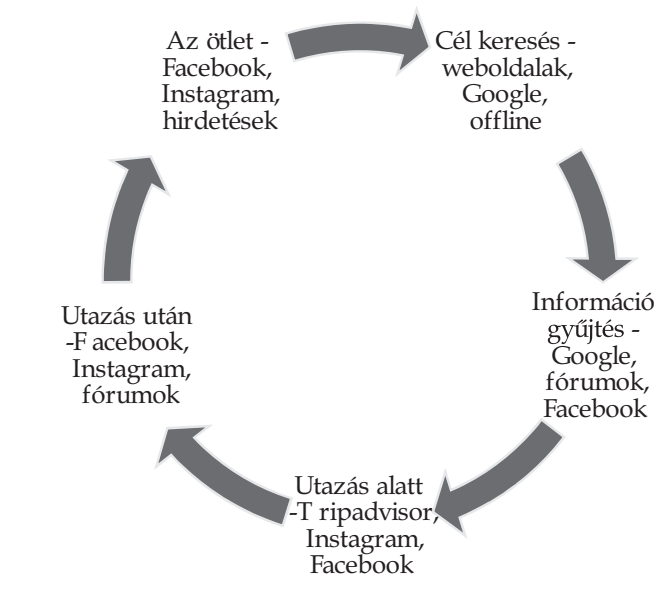

Forrás: saját szerkesztés LÉVAI R. (2013)7 alapján

Egy külföldi felmérés megállapítja, hogy a turisták utazás elótti döntéshozatalát, illetve az utazás közbeni tájékozódását 16\%-ban a közösségi oldalakon látottak befolyásolják (IVÁNYI - BÍRÓ-SZIGETI 2016). Több kutatás is bizonyítja, hogy fốként a fiatalok (a közvetlen ismerősök, barátok véleménye mellett) jobban bíznak más utazók és a közösségi portálok véleményeiben, vagyis az online szájreklámban, mint az utazási irodák vagy a hagyományos kommunikációs csatornák (TV, rádió, újság) ajánlásaiban (FOTIS et al. 2012, ŽIVKOVIĆ et al. 2014). Bár OKLOBDŽIJA (2015) szerint a szájreklám a leginkább veszélyeztetett és legkevésbé szabályozható területe a közösségi hálón való kommunikációnak, ugyanakkor tény, hogy ebból lehet a legtöbbet profitálni.

A közösségi média platformok ma már domináns kommunikációs csatornákká fejlődtek (HUDSON et al. 2015).A statisztikák szerint a világon minden 4 . ember használ legalább egy közösségi hálózatot (OKLOBDŽIJA 2015). A mai fiatalok, vagyis a digitális bennszülöttek jelentős része élményekre vágyik, és nem szeretne semmirôl lemaradni, ezért többségük használja a különböző közösségi oldalakat (például Facebook), a fotó- és videómegosztó portálokat (például Instagram), és a turizmushoz köthetô speciális oldalakat (például TripAdvisor). Ezeknek az oldalaknak nagy elónye, hogy az itt megosztott tapasztalatok, élmények hosszabb időre megmaradnak, gyorsan kereshetôvé válnak, és folyamatosan frissíthetók, bóvíthetốk. Az MT Zrt. (2013) jelentése szerint tízből több mint nyolc felhasználó állítja, hogy mások közösségi oldalakra feltöltött hozzászólásai, videói,

$\overline{{ }^{7} \mathrm{https} / / / \text { www.slideshare.net/ricsi1/mszesz-konfprezi20131122 }}$
A közösségi oldalak, illetve a kép- és videómegosztó portálok esetében - amelyek a közösség építését, az egyének közötti kommunikációt szolgálják - egyre inkább megfigyelhetó a marketing szemléletú felhasználás, ami innováció a turizmusmarketing eszköztárában is (IVÁNYI - BÍRÓ-SZIGETI 2016). A közösségi médiának ugyanis nagy elónye, hogy segítségével viszonylag gyorsan és olcsón sokan elérhetővé válnak, ráadásul az egyre fejlettebb technológiáknak köszönhetően személyre szabottan lehet megszólítani a vásárlókat. Másik előnye, hogy az itt található bejegyzések nem csak a többi felhasználónak nyújtanak információt, hanem a szolgáltató számára is fontos visszacsatolás lehet egy termék, vagy szolgáltatás sikerességéról.

Tanulmányunkban két fesztivál példáján vizsgáltuk a közösségi média szerepét, ezért a következő fejezetben röviden ismertetjük a fesztiválok, különösen a zenei fesztiválok turisztikai kínálatban betöltött helyét és szerepét, illetve röviden bemutatjuk, hogy milyen jelentôsége lehet a közösségi médiának a fesztiválturizmusban.

\section{Fesztiválturizmus}

\subsection{A FESZTIVÁLOK HELYE ÉS JELENTÓSÉGE A TURIZMUS RENDSZERÉBEN}

A fesztiválturizmus a kulturális turizmus egy speciális (eseményekhez, programokhoz) kötött terméke. A kulturális turizmust - igen tág értelmezésben - CSAPÓ - MATESZ (2007) úgy határozzák meg, hogy magában foglal minden olyan turisztikai szegmenst, amely nem a tömegturizmust növeli. Ez a definíció jól tükrözi, hogy napjainkban egyre nagyobb szerephez jut a kultúra, szinte minden (a klasszikus tömegturizmustól eltéró) utazásnak van kulturális vonatkozása (KOVÁCS - NAGY 2013).

A fesztiválok a kulturális turizmuson belül az épített, tárgyi értékek, és a mindennapi élethez kapcsolódó kulturális értékek mellett jelennek meg (CSAPÓ - MATESZ 2007). Megfigyelhető, hogy a kulturális turizmuson belül leginkább a fesztiválturizmus iránt nőtt meg a kereslet, egyrészt mert a fesztiválhangulat egy olyan nem mindennapi élményt ad, mely fontos motiváció az utazási döntés meghozatalánál (ZÁTORI 2016), másrészt egyre több fesztivál jelenik meg a turisztikai piacon, hiszen a fesztiválok komplex termékek, jól azonosítható márkával rendelkeznek, így erre versenyképesebb imázst építhetnek az egyes desztinációk. Emellett a látogatottság és az ismertség növeléséhez is hozzájárulhatnak azáltal, hogy élénkítik a település kulturális kínálatát (KAZÂR 2014). 
A fesztiválok a közvetlen bevételek által pozitív hatást gyakorolhatnak a helyi gazdaságra, hiszen éves költségvetésük 8-10 milliárd forintra tehető ${ }^{8}$, de közvetett haszonnal is számolni lehet, amely jelentős része a helyi infra- és szuprastruktúránál realizálódik (JÁSZBERÉNYI 2016). A fesztiválok gazdasági szerepe az adott desztináció turizmusának serkentése mellett a figyelemfelkeltő, promóciós és márkaépítő hatásban is megnyilvánulhat, melyhez hatékony kommunikációs csatornát biztosít a közösségi média.

Kulturális értékteremtésról akkor lehet beszélni, ha a hagyományok órzésére, a magaskultúrára, illetve a fogyasztói élmény minőségére nagyobb hangsúlyt helyeznek (ZÁTORI 2016). Általános vélekedés, hogy a kisebb fesztiválok gyakran több értéket és hagyományt képviselnek, melyek a lakosok helyhez kötődés érzését erôsíthetik. Ezek kevés esetben válnak nagyobb turisztikai attrakcióvá. A nagyobb méretú fesztiválok pedig üzleti célúak, kevésbé fektetnek hangsúlyt a kulturális értékekre, viszont pozitív hatásuk lehet a gazdasági folyamatokra, és hozzájárulhatnak egy-egy desztináció megismeréséhez, imázsának (ki)alakításához (SULYOK - SZIVA 2009). Több eset is említhető, ahol egy-egy település az ott megrendezett fesztivál által vált ismertté, például Avignon (Festival d'Avignon), Edinburgh (Ószi Edinburghi-fesztivál), vagy Salzburg (Salzburgi Ünnepi Játékok) (BENEDEK - STARK 2009). Ha elég szoros az esemény és a desztináció együttmúködése, akkor a fesztivállal kapcsolatos pozitív tapasztalatok, élmények a desztináció előnyévé is válnak. OKLOBDŽIJA (2015) ezt a folyamatot imázsátvitelnek nevezi, melynek közvetítésében a közösségi médiának kiemelt szerepe van napjainkban. Az esemény és a desztináció közötti gyenge kapcsolat viszont negatív márkaépítést és negatív imázstranszfert okozhat, ezért több szempontból is vizsgáltuk a fesztiválok és a települések kapcsolatát.

A fesztiválok társadalmi szerepe a fesztiválhangulatban is megnyilvánulhat, de a megélt élmény esetében különbséget kell tenni a helyiek és a turisták tapasztalatai között (PAVLUKOVIĆ et al. 2017). Utóbbinak a fesztiválélmény mellett turisztikai élményben is része van, hiszen látogatóként érkezik az adott desztinációba. A fesztiválok pozitív hatással lehetnek a helyiek életminőségére (MICHALKÓ 2010), a megélt élményekre pedig mind a helyiek, mind az odalátogatók sokáig szívesen tekintenek vissza (ZÁTORI 2016), melyhez jó alapot kínál a közösségi média használata.

\footnotetext{
${ }^{8}$ Becsült adat, amelyet a Magyar Fesztivál Szövetség, a Magyar Művészeti Fesztiválok Szövetsége és a Folklórfesztiválok Magyarországi Szövetsége által regisztrált, 300 fesztivál által szolgáltatott adatokból számítottak és vetítettek a Magyarországon ma - szintén becslés alapján - megrendezésre kerülő 6000 fesztiválra.
}

A fesztiválok turisztikai hatásai közül kiemelhető egyediségük, hiszen nemcsak a fellépők, hanem a közönség is szerves része az eseménynek, így nincs két egyforma fesztivál, melyek így erôsíthetik a fogadóterület turisztikai vonzerejét. Az események bővíthetik a kulturális kínálatot, meghosszabbíthatják a turisztikai szezont, és megfeleló marketinggel addig ismeretlen desztinációkat is bekapcsolhatnak a kínálatba, vagy egyes településeket imázsuk megváltoztatásával ismertebbé tehetnek. Mindezek alapján nem véletlen, hogy egyre több település ad otthont valamilyen fesztiválnak (VÁRHELYI 2016).

\subsection{A KÖNNYÜZENEI FESZTIVÁLOK}

A fesztiválok témájukat tekintve rendkívül sokfélék lehetnek, de különösen a zenei fesztiválok azok, amelyek egyre népszerúbbek, turisták millióit vonzzák (HUDSON et al. 2015). Az utóbbi évtizedekben a zene - különböző múfajokban és formákban - mint utazási motiváció egy gyorsan terjedó új turisztikai trendként jelent meg, ezáltal egy folyamatosan bővülő iparággá nőtte ki magát a turizmus piacán (GIBSON - CONNELL 2005). Ehhez hozzájárult az is, hogy a web 2.0 technológiáknak köszönhetően a zenei fesztiváloknak lehetősége van jóval olcsóbban és nagyobb léptékben megszólítani a potenciális közönséget.

Zenei fesztivál alatt egyrészt könnyứ-, másrészt komolyzenei fesztiválokat értünk. Előbbihez sorolhatók például a pop-, rock-, jazz-fesztiválok, míg az utóbbihoz a szimfonikus zenekari és opera fesztiválok tartoznak (SZABÓ 2014). Bár már korábban is találkozhattunk könnyúzenei fesztiválokkal (például az 1969-es elhíresült Woodstock Festival), igazi elterjedésük fordulópontját az 1982-es nagy britanniai Glastonbury Festival-hoz kötik (SMITH 2009). A hazai nyári könnyúzenei fesztiválok közül az EFOTT rendelkezik a legrégebbi gyökerekkel, 1976-ban jött létre (BÁCSNE BÁBA 2014). Napjainkban már nagyon sok országban rendeznek könnyúzenei fesztiválokat, a vizsgált országokat nézve példaként említhetô hazánkban a VOLT, a Sziget, a Balaton Sound, a SZIN, vagy Szerbiában az Exit, illetve a Green Future fesztivál.

A könnyúzenei fesztiválok a fiatalok körében sikeresebbek és látogatottabbak, a szervezők elsősorban az ő zenei ízlésüket (is) célozzák meg. VÁGI (2009) kutatása, melyet a hazai aktív kulturális közönség körében végzett, megállapítja, hogy a résztvevők 71\%-ban 30 év és 94\%-ban 54 év alattiak, illetve több köztük a férfi, mint a nó. A tanulók kiemelkedő jelenléte is meghatározó, hiszen majdnem felét teszik ki a résztvevóknek (48\%). A fesztivállátogatási szokásokat vizsgálva azt is meg- 
Lektorált tanulmányok

állapította, hogy lakóhelyen és azon kíviul is egyre népszerúbb a fesztiválokon való részvétel, és egyre nagyobb távolságokat hajlandóak megtenni a turisták egy-egy esemény meglátogatása céljából. Ez a technológia robbanásszerú fejlődésének is köszönhető, hiszen az utazási döntést mára már a közösségi média is jelentôsen befolyásolja.

Kutatásunk alapjának azért választottunk két könnyúzenei fesztivált, mert ezek egyre több - elsősorban fiatal - turistát vonzanak, akik túlnyomó többsége használja a közösségi hálózatokat, így körükben alkalmasnak találtuk a közösségi média fesztiválturizmusban betöltött szerepének vizsgálatát. Kérdőíves felmérésünkben vizsgáltuk azt is, hogy a fesztiváloknak milyen hatásait érzékelik a megkérdezettek, illetve asszociációk és az Instagramon közzétett bejegyzések elemzésével igyekeztünk feltárni, hogy mennyire szoros a kapcsolat a desztináció és a fesztivál között, mennyiben járul hozzá ezáltal a fesztivál a település ismertségének növeléséhez. Kutatásunk idevonatkozó legfőbb eredményeit a következő fejezet mutatja be.

\section{A fesztivállátogatók körében végzett felmérés fơbb eredményei}

A kutatás során vizsgáltuk a fesztiválok gazdasági, társadalmi, kulturális, környezeti, illetve imázsra gyakorolt hatásának megítélését a fesztivál látogatói körében, hiszen ez kiindulási alapot adhat arról, hogy milyen vélemények, tapasztalatok megjelenése várható a közösségi médiában. A kérdőívben Likert-skálán (1-tól 5-ig) kellett értékelniük a válaszadóknak, hogy mennyire értenek egyet a fesztivál hatásaira vonatkozó állításokkal. A Green Future esetében a legtöbben azzal értettek egyet, hogy a fesztivál elsósorban közösségi élményt biztosít és szórakoztatást nyújt $(4,49)$. A SZIN-en a megkérdezett látogatók véleménye szerint a fesztivál elsősorban Szeged hírnevének növeléséhez járul hozzá $(4,52)$, de a Green Future résztvevői is egyetértettek azzal, hogy Ada esetében is jelentős kapcsolat van a település és a fesztivál között $(4,48)$. A fesztiválozók véleménye szerint ezek az események nem csak a hírnévre vannak hatással, hanem növelik a települések és környékük idegenforgalmát (Green Future: 4,38; SZIN: 4,23), illetve létrehoznak egy az ezekhez a településekhez köthetó arculatot is (Green Future: 4,07; SZIN: 4,21), tehát az imázs építésében, javításában is szerepük van (2. ábra).

Az imázsalakító hatást a kutatás során egy másik kérdés kapcsán is vizsgáltuk, amikor arról kérdeztük a fesztiválozókat, hogy mi jut elsőként eszükbe Adáról vagy Szegedról. Itt megjegyeznénk, hogy bár a kérdóívben ez volt a legelső kérdés, a válaszokat ennek ellenére biztosan be- folyásolta, hogy a fesztivál helyszínén végeztük a felmérést. A településre vonatkozó asszociációk a Green Future esetében voltak jelentősebbek (51\%), ami nem véletlen, hiszen egy kisebb településről van szó, kevesebb turisztikai termékkel, így sokan magáról a fesztiválról ismerik a települést.

\section{A fesztiválok legjelentősebbnek vélt} pozitív hatásai

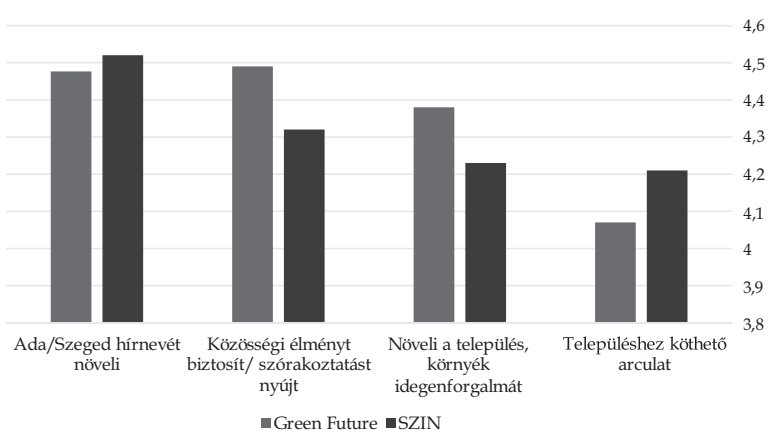

Forrás: saját szerkesztés a kérdőíves felmérés (2017) alapján

A desztináció és fesztivál közötti imázstranszfert a kérdőíven kívül az Instagram bejegyzésekben is vizsgáltuk, abból a feltételezésból kiindulva, hogy minél szorosabb ez a kapcsolat, annál nagyobb arányban tesznek említést a fesztiválra vonatkozó bejegyzésekben magukról a településekról is. Az asszociációkkal szemben a vizsgált hashtagek esetében a SZIN-en jelölték be többen a települést, a 645 bejegyzésből 252-ben említették Szegedet is valamilyen formában (39\%). A Green Future esetében a 211 bejegyzésból mindössze 29 alkalommal találtunk Adára történő utalást (14\%). A SZIN esetében leggyakrabban magát \#szeged-et tagelték be (197 db), de a \#szeged \#iloveszeged (14 db) és a \#szeged \#suncity (10 db) címszavak együttesen is előfordultak, illetve Szeged egyéb részeire is találtunk utalást (dóm, Tisza-part, partfürdő). A Green Future esetében a leggyakoribb hashtag szintén maga a település, vagyis \#ada volt (20 db), ezen kívül szerepelt még az \#adica és az \#adatour is.

A negatív hatások közül a szemetelést (Green Future: 3,91; SZIN: 3,44) és a megnövekedett zajt (Green Future: 3,97; SZIN: 3,74) emelték ki mindkét fesztivál esetében, illetve a Green Future-ön a káros szerek használatának fokozódását $(3,60)$, a SZIN-en pedig a helyiek zavarását hangsúlyozták $(3,35)$. Menedzsment szempontból az ezekkel kapcsolatos bejegyzésekkel érdemes a közösségi médiában is foglalkozni, hiszen jelentôsen ronthatják az esemény és ezáltal a település imázsát. $\mathrm{Az}$ is kiderült a felmérésból, hogy a Green Future 
esetében a látogatók úgy érzik, hogy a fesztivál nem járul hozzá Szerbia hírnevének növeléséhez, bár véleményük szerint erre a jövőben van esély, jelenleg csak lokális hatása érezhetô. Ezen kívül a megkérdezettek szerint a kábítószer használat mellett egyéb búncselekmények növekedésére (például rablás, rongálás) nincs hatással a fesztivál. A SZIN esetében a válaszadók szerint a fesztiválnak nincs hatása sem a káros szerek használatára, sem az egyéb búncselekmények fokozódására.

Kíváncsiak voltunk, hogy az a - fentebb említett - tendencia, miszerint az információszerzést, utazási döntéshozatalt jelentősen befolyásolják a közösségi oldalakon látottak, a megkérdezettek körében is megfigyelhető-e. A fesztiválról való tájékozódást vizsgálva megállapítható, hogy a Green Future fesztiválon bár a megkérdezettek legnagyobb része még mindig az ismerősöktól, barátoktól személyesen szerzett információt részesíti elônyben, a második helyen már a Facebook közösségi oldal szerepel. Persze ezen a közösségi felületen elsősorban szintén az ismerősök, barátok kapnak szerepet, tehát tulajdonképpen a hagyományos információszerzést erősíti fel egy új eszközzel/csatornával, illetve bóvíti a lehetôségeket azáltal, hogy számunkra ismeretlenek (ismerôseink ismerőseinek) bejegyzéseit/ajánlásait is láthatóvá teszi. A SZIN esetében legtöbben ismerőstól, baráttól hallottak a fesztiválról, illetve egy részük régebb óta ismeri, de szintén megjelenik a Facebook, mint információforrás.

Az online információszerzés mellett az élmények interneten való megosztásának népszerúségét is igazolja a kutatás, hiszen a Green Future-ön a megkérdezettek $78 \%$-a, a SZIN-en pedig 55\%-a megosztja valamilyen közösségi felületen az élményeit. A Green Future fesztivál esetében a magas százalékos arány a korosztálynak is köszönhetó, hiszen ez a fesztivál egy fiatalabb generációt vonz. Az adai fesztiválon elsősorban az Instagramot és annak hashtag funkcióját használják az élmények megosztására, mely a fiatalok körében napjainkban a legnépszerúbb, képeket és videókat megosztó csatorna, melyet a Facebook követ. A Szegedi Ifjúsági Napokon a fesztiválozók elsősorban a Facebookon osztják meg élményeiket, majd ezt követi az Instagram. A Facebook és az Instagram használatának eltérései a területi különbségekre is visszavezethetők, hiszen Magyarországon kiemelkedő a Facebook közösségi csatorna használata. Mindkét fesztivál esetében harmadik helyen a Szerbiában és Magyarországon is egyre népszerúbbé váló Snapchat következik (3.ábra).
3. ábra

Az élmények megosztásának eloszlása (a megosztók száma alapján) az online közösségi felületeken

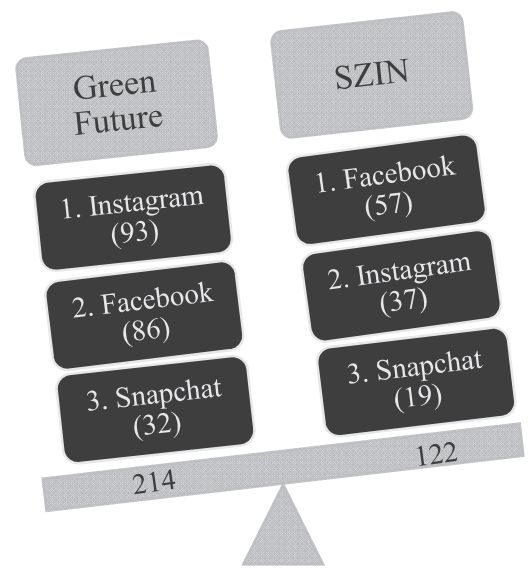

Forrás: saját szerkesztés a kérdőíves felmérés (2017) alapján

Az élmények megosztása során a Green Future-ön az Instagram már megelózi a Facebook közösségi oldalt, ami a vizsgált fiatalabb korösszetétellel van összefüggésben, hiszen a fiatalabbak a legújabb trendeket követve már inkább ezt a felületet használják megosztásra, viszont ha a bejegyzések kereséséról van szó, akkor a Facebook dominál. A fesztiválozók ugyanis kíváncsiak mások közétett bejegyzéseire is, amihez viszont még mindig a Facebook szolgáltatja a legjobb (legtöbb ember által használt) alapot. Azonban a Facebook mellett az Instagram és a Youtube közösségi csatornák is megjelennek, illetve a SZIN szélesebb körú közönsége révén a Google keresôt is magasabb arányban használják (4. ábra).

\section{4. ábra}

Bejegyzések keresésének megoszlása a különbözó online közösségi felületeken

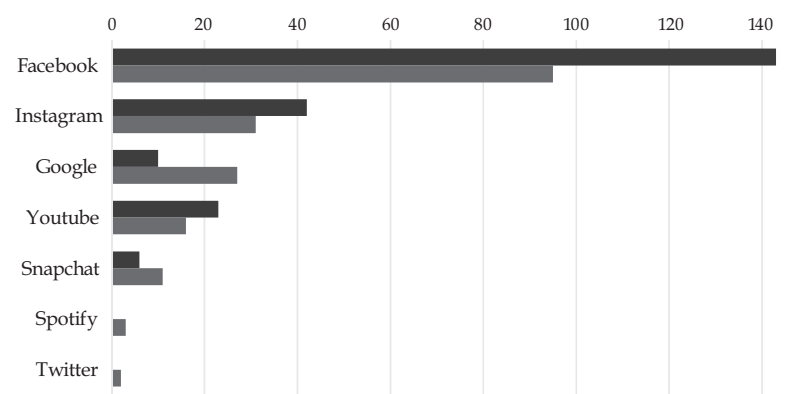

- Green Future $\boldsymbol{\text { SZIN }}$

Forrás: saját szerkesztés a kérdőíves felmérés (2017) alapján 
Lektorált tanulmányok

Arra is kíváncsiak voltunk, hogy vajon a fesztiválozók milyen bejegyezéseket tekintenének meg szívesen a fesztiválról a közösségi médiában. A bejegyzések között legnagyobb gyakorisággal mindkét fesztiválon a képeket, a videókat és az aftermovie ${ }^{9}$-t említették a megkérdezettek, illetve a válaszok között felmerült az élő videó/élő bejelentkezés igénye is (5. ábra). A fesztiválnak otthont adó településre vonatkozó adatok, információk megtekintése viszont egyáltalán nem jelent meg a válaszokban.

A fesztiválozók által legkeresettebb online bejegyzések

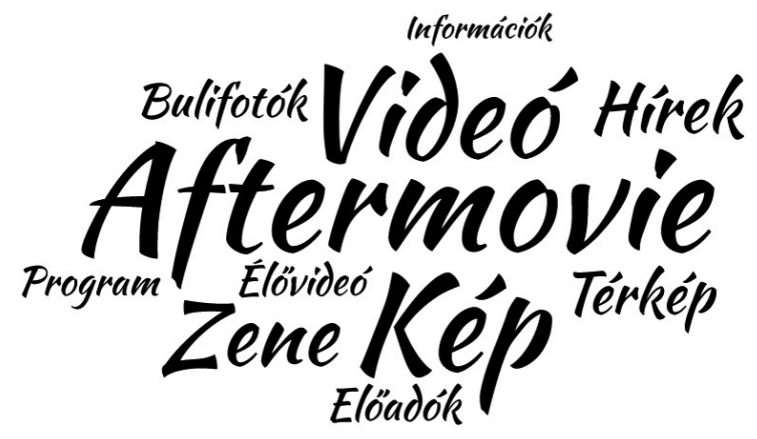

Forrás: saját szerkesztés a kérdőíves felmérés (2017) alapján

Ma már egyes fesztiválok, mint például a VOLT és a Sziget, indítanak éló közvetítést, így a hangulat egy szeletét azok is élvezhetik, akik valamilyen okból nem tudtak eljutni a fesztiválra. Ezt nem csak az események szervezói tehetik meg, hanem a közönségnek is lehetősége van különböző közösségi felületeken online bejelentkezést indítani. A Green Future fesztiválon a megkérdezettek 14\%-a indít éló videót/bejelentkezést a fesztiválról Facebookon vagy Instagramon, míg a SZIN-en ez az arány $29 \%$. (Ennek oka a területi különbségekben valószínúsíthető, hiszen Szerbiában még nem anynyira elterjedt funkció az élő bejelentkezés.) Az éló videó funkciónak természetesen lehet a turizmus számára negatív oldala, hiszen otthonról, kényelmesen, költségek nélkül is követni tudja egy szélesebb közönség a koncerteket és az eseményeket, de a valódi élményt keresô turistát (GONDOS - HERCZ 2011, ZÁTORI 2014) pozitívan is befolyásolhatja, hiszen ösztönözheti az utazási döntés meghozatalára.

A turizmusban - így a fesztiválturizmusban is - a kínálati elemek olyan nagy versenye figyelhetó meg, ami a kreatív, innovatív ötleteket teszi szüksé-

\footnotetext{
${ }^{9}$ a fesztivál után elkészített összefoglaló videó
}

gessé. Ilyen innovatív eszközök például a mobilapplikációk (OROSZI - GONDA 2016), melyek közül egyre több érhetô el a turisztikai piacon is, hatást gyakorolva a turisztikai forgalomra (PÁLFI 2016). A Green Future fesztivál nem rendelkezik ilyen applikációval, azonban a megkérdezett fesztiválozók 36\%-a használná, ha lenne. Legnagyobb számban a koncertek és a programok időpontjai után érdeklódnének, illetve fontosnak tartják az együttesekre és fellépókre vonatkozó információkat is. A SZIN-nek van alkalmazása okostelefonra, melyet a megkérdezett fesztiválozók 35\%-a igénybe is vesz. A funkciók közül az együttesek/koncertek időpontjait, illetve a térképet használták legtöbben, de a festipay-fizetés funkció is nagy számban fordult eló.

\section{6. Összegzés}

A fesztiválturizmus, mint turisztikai termék, napjainkra nagyon komplex és a társadalom jelentôs részét érintố jelenséggé vált. Egyre több potenciális turista utazási döntésében jelenik meg mint külön motiváció, és ezek az események szerepet játszhatnak egy adott desztináció megismerésében is.

A fesztiváloknak, azáltal hogy egyedi márkát képviselnek, jelentős imázserôsító hatásuk lehet. Ez a hatás felmérésünk során megmutatkozott például abban, hogy a megkérdezettek Szegedet fiatalos, lendületes városnak tartják, Ada esetében pedig a fesztiválra asszociálnak, és jelentősnek tartják azt a város életében. Emellett a fesztivállal kapcsolatos bejegyzéseikben megjelent a város említése, így a megosztott élmények nem csak az adott fesztivál, hanem a települések népszerúségének növeléséhez is hozzájárulhatnak. Ugyanakkor a Green Future esetében ez az imázstranszfer jóval gyengébb, hiszen a vizsgált bejegyzések csupán 14\%-ában jelenik meg a település, míg a SZIN esetében 39\%-ban jelölték meg a várost. Kutatásunkban igazolódott, hogy az élmények megosztása egyre népszerúbb a fiatalok körében, a Green Future-ön a megkérdezettek $78 \%$-a, a SZIN-en pedig $55 \%$-a osztja meg valamilyen közösségi felületen az élményeit. Az elkészített fotó, videó vagy élő bejelentkezés azonnal felkerül valamilyen közösségi oldalra (például Facebook), vagy kép-, illetve videómegosztó portálra (például Instagram), így az élmény nem csak egy pillanat a turista számára. Ráadásul a bejegyzésnek köszönhetóen ezt az élményt nem csak ő éli át, hanem a barátok, ismerősök és akár teljesen ismeretlen emberek is részesei lehetnek. Ezzel kapcsolatban azonban felvetődik a kérdés, hogy ez a turizmusnak elôny vagy hátrány? Amennyiben a megosztott élmény pozitív, az másokban is utazási szándékot generálhat. Ugyanakkor egy-egy rossz tapasztalat, negatív megosztott tartalom az utazás 
ellen hathat, csökkentve vagy akár teljesen megszüntetve a motivációt.

A fesztiválozók nem csak megosztani szeretnek, hanem kíváncsiak mások közzétett bejegyzéseire is. Bár a Green Future esetében a fiatalabb korosztálynak köszönhetően a megosztások terén már az Instagram dominál, a bejegyzések keresésekor mindkét fesztivál esetében még mindig a Facebook szolgáltatja a legjobb (legtöbb ember által használt) alapot. A Facebook, mint leggyakrabban használt közösségi csatorna, főként barátaink, ismerőseink, esetleg az ô ismerôseik körében befolyásolhatja az utazási szándékot. Viszont a legújabb trendeknek köszönhetően az Instagram térnyerésével, a hashtagek adta lehetőséget kihasználva, címszavak segítségével kereshetünk helyekre, eseményekre, így különbözó személyek képeit, megosztásait követhetjük anélkül, hogy ismernénk, ami még szélesebb körben befolyásolhatja az utazási döntéseket, és új lehetőségeket ad a turizmus, ezzel együtt a fesztiválturizmus számára.

A kutatás eredményeinek korlátaival kapcsolatban fontos megemlíteni, hogy a vizsgált 18-25 éves korosztály a Green Future esetében erôsen felülreprezentált lett, ugyanis a felmérés során kiderült, hogy ezen a fesztiválon a fesztiválozók egy jelentős része 18 éven aluli volt. Ez további érdekes kérdéseket és jövőbeni kutatási lehetőségeket vet fel. Kutatásunk további tervezett iránya a nyári kutatáshoz kapcsolódóan egy online kérdőíves felmérés elvégzése az egyetemisták körében. Elsősorban arra keresnénk a választ, hogy miként és mire használják a közösségi médiát a fesztiválokkal kapcsolatban, hogyan vélekednek a fesztiválok hatásairól, és a válaszaik alapján mely fesztivál-település páros esetében mutatható ki a legjelentősebb imázserôsítő kapcsolat. A kérdőívekben megjelenő fesztivál hatások összevetése a közösségi médiában elérhető tartalmakkal szintén jövőbeli kutatási cél.

\section{Felhasznált irodalom}

BÁCSNÉ BÁBA É. (2014): Hallgatók, buli, Campus - Felsőoktatási hallgatók fesztivállátogatási szokásainak vizsgálata a Campus Fesztiválon. Turizmus Bulletin. 16(2). pp. 34-41.

BENCKENDORFF, P. - SHELDON, P. - FESENMAIER, D. (2014): Tourism information techno$\log y$. CABI, UK.

BENEDEK M. - STARK J. (2009): Fesztiválvilág. Turizmus Bulletin. 13(3). pp. 35-45.

BUHALIS, D. - LAW, R. (2008): Progress in information technology and tourism management: 20 years on and 10 years after the Internet - The state of eTourism research. Tourism Management. 29(4). pp. 609-623.
CROMPTON, J. L. - McKAY, S. L. (1994): Measuring the Economic Impact of Festivals and Events: Some Myths, Misapplications and Ethical Dilemmas. Festival Management and Event Tourism. 2(1). pp. 33-43.

CSAPÓ J. - MATESZ K. (2007): A kulturális turizmus jelentősége és szerepe napjaink idegenforgalmában. Földrajzi Értesítô. 56(3-4). pp. 291-301.

DUDÁS, G. - BOROS, L. - VIDA, GY. (2017): Comparing the temporal changes of airfares on online travel agency websites and metasearch engines. Tourism. 65(2). pp. 187-203.

ÉBER M. Á. (2008): Túl az élménytársadalmon? avagy az élménytársadalom másfél évtizede. Szociológiai Szemle. 18(1). pp. 78-105.

ESZES I. (2007): Web 2.0. ESZES könyvtár. http:// www.eszes.net/eTanulmanyok/web2.pdf, Letöltve: 2017. szeptember 6 .

FOTIS, J. - BUHALIS, D. - ROSSIDES, N. (2012): Social media use and impact during the holiday travel planning process. In: Fuchs, M. - Ricci, F. - Cantoni, L. (eds): Information and Communication Technologies in Tourism. pp. 13-24.

GIBSON, C. - CONNELL, J. (2005): Music and Tourism: On the Road Again. Aspects of Tourism. Channel View Publications, Clevedon.

GONDOS B. - HERCZ Á. (2011): A kulturális tevékenységek hatása az életminőségre. In: Róbert P. (szerk.): "Magyarország társadalmi-gazdasági helyzete a 21. század elsố évtizedeiben". Kautz Gyula Emlékkonferencia, SZIE, Győr. Elektronikus kötet.

HUDSON, S. - ROTH, M. - MADDEN, T. HUDSON, R. (2015): The effects of social media on emotions, brand relationship quality, and word of mouth: An empirical study of music festival attendees. Tourism Management. 47. pp. 68-76.

IVÁNYI T. - BÍRÓ-SZIGETI SZ. (2016): Oszd meg és hashtagelj! - Közönségrészvétel és élménymegosztás a turizmusban. In: Fehér A. - Kiss V. A. - Soós M. - Szakály Z. (szerk.): Hitelesség és értékorientáció a marketingben. Debreceni Egyetem Gazdaságtudományi Kar, Debrecen. pp. 706-715.

JÁSZBERÉNYI M. (2016): A fesztiválok gazdasági hatása. In: Jászberényi M. - Zátori A. - Ásványi K. (szerk.): Fesztiválturizmus. Akadémiai Kiadó, Budapest. pp. 34-44.

KAZÁR K. (2014): Fesztivállátogatást befolyásoló tényezôk vizsgálata fókuszálva a márka szerepére. In: Hetesi E. - Révész B. (szerk.): „Marketing megújulás". Marketing Oktatók Klubja 20. Konferenciája, Szegedi Tudományegyetem, Gazdaságtudományi Kar, Szeged. Elektronikus kötet. 
Lektorált tanulmányok

KLAUSZ M. (2017): Megosztok, tehát vagyok: Szakértôi kérdések és válaszok a közösségi médiáról. Athenaeum Kiadó, Budapest.

KOVÁCS D. (2014): Élmény, élménygazdaság, élménytársadalom és turizmus. Turizmus Bulletin. 16(3-4). pp. 40-48.

KOVÁCS, I. - NAGY, GY. (2013): Tourism in peripheric regions - the possibilities of thematic routes. Analele Universitătii din Oradea - Seria Geografie. 23(2). pp. 220-228.

KUNDI V. (2012): A fesztiválok városokra gyakorolt gazdasági- és társadalmi-kulturális hatásainak elemzése. Értekezés tervezet, Győr.

LIANG, Y. - ILLUM, S. F. - COLE, S. T. (2008) Benefits received and behavioural intentions of festival visitors in relation to distance travelled and their origins. International Journal of Event Management Research. 4(1). pp. 12-23.

MICHALKÓ G. (2010): Boldogító utazás. A turizmus és az életminôség kapcsolatának magyarországi vonatkozásai. MTA Földrajztudományi kutatóintézet, Budapest.

MT Zrt. (2013): A közösségi média hatása a turizmusra. Budapest. http://egeszsegturizmus.itthon. hu/documents/28123/4381875/Mintel_The_ impact_of_social_media_on_tourismx.pdf/ f921e947-7352-49a5-8659-50a7a165469d, Letöltve: 2017. szeptember 24.

OKLOBDŽIJA, S. (2015): The role and importance of social media in promoting music festivals. Synthesis: Marketing and Trade. pp. 583-587.

OROSZI V. - GONDA T. (2016): Az innováció értelmezése és gyakorlata a turizmusban. Területfejlesztés és innováció. 10(1). pp. 3-20.

PÁLFI A. (2016): Turisztikai desztináció menedzsment szervezetek szerepe az innovációk elterjedésében Magyarországon. In: Ivancsóné Horváth Zs. - Darabos F. (szerk.):,"Turizmus és Innováció". VIII. Nemzetközi Turizmus Konferencia tanulmányok, SZIE, Győr. pp. 40-51.

PAVLUKOVIĆ, V. - ARMENSKI, T. - ALCÁNTARA-PILAR, J. M. (2017): Social impacts of music festivals: Does culture impact locals' attitude toward events in Serbia and Hungary? Tourism Management. 63. pp. 42-53.
SMITH, M. (2009): Fesztiválok és turizmus: lehetőségek és konfliktusok. Turizmus Bulletin. 13(3). pp. 23-28.

SULYOK J. (2016): A magyarországi fesztiválturizmus országos szintû́ marketingje. In: Jászberényi M. - Zátori A. - Ásványi K. (szerk.): Fesztiválturizmus. Akadémiai Kiadó, Budapest. pp. 97-107.

SULYOK J. - SZIVA I. (2009): A fesztiválturizmus nemzetközi és hazai tendenciái. Turizmus Bulletin. 13(3). pp. 3-13.

SZABÓ J. Z. (2014): A fesztiváljelenség. Typotex Kiadó, Budapest.

VÁGI B. (2009): A hazai aktív kulturális közönség vizsgálata a Reneszánsz Év - 2008 keretében. Turizmus Bulletin. 13(3). pp. 48-57.

VÁRHELYI T. (2016): A fesztiválturizmus szinergiái. In: Jászberényi M. - Zátori A. - Ásványi K. (szerk.): Fesztiválturizmus. Akadémiai Kiadó, Budapest. pp. 44-54.

VERES I. - DANÓ GY. - IVÁNYI T. (2017): Oszszunk vagy ne osszunk? Fiatalok utazási szokásai és élménymegosztás. In: Bányai E. - Lányi B. - Törőcsik M. (szerk.): Tükrözôdés, társtudományok, trendek, fogyasztás. Pécsi Tudományegyetem, Közgazdaságtudományi Kar, Pécs. pp. 75-84.

XIANG, Z. - GRETZEL, U. (2010): Role of social media in online travel information search. Tourism Management. 31(2). pp. 179-188.

XIANG, Z. - WANG, D. - O'LEARY, J. T. - FESENMAIER, D. R. (2014): Adapting to the Internet: Trends in Travelers' Use of the Web for Trip Planning. Journal of Travel Research. 54(4). pp. 511- 527.

ZÁTORI A. (2014): Élményszemlélet a turizmusban. A turisztikai élményteremtés koncepciói. Turizmus Bulletin. 16(2). pp. 51-60.

ZÁTORI A. (2016): A fesztiválturizmus elméleti aspektusai. In: Jászberényi M. - Zátori A. - Ásványi K. (szerk.): Fesztiválturizmus. Akadémiai Kiadó, Budapest. pp. 15-33.

ŽIVKOVIĆ, R. - GAJIĆ, J. - BRDAR, I. (2014): The impact of social media on tourism. Sinteza: E-Business in tourism and hospitality industry. pp. 758-761. 